\title{
Effect of Fluoride Ion on the Separation of Fluorite from Calcite Using Flotation with Acidified Water Glass
}

\author{
Daqian Wang ${ }^{1,2} \mathbb{D}$, Dan Liu ${ }^{1,2, *}$, Yingbo Mao ${ }^{2,3, *}$, Ruofan Sun ${ }^{1,2}$, Ruitao Liu ${ }^{1,2}$ and Shuming Wen ${ }^{1,2}$ \\ 1 Faculty of Land Resource Engineering, Kunming University of Science and Technology, \\ Kunming 650093, China; daqianwang1997@163.com (D.W.); srfyyds1996@126.com (R.S.); \\ lrtao_1997@163.com (R.L.); shumwen@126.com (S.W.) \\ 2 State Key Laboratory of Complex Nonferrous Metal Resources Clean Utilization, Kunming University of \\ Science and Technology, Kunming 650093, China \\ 3 School of Chemistry and Resources Engineering, Honghe University, Mengzi 661100, China \\ * Correspondence: ldysyz1983@126.com (D.L.); maoyingbo86@126.com (Y.M.)
}

Citation: Wang, D.; Liu, D.; Mao, Y.; Sun, R.; Liu, R.; Wen, S. Effect of Fluoride Ion on the Separation of Fluorite from Calcite Using Flotation with Acidified Water Glass. Minerals 2021, 11, 1203. https://doi.org/ $10.3390 / \min 11111203$

Academic Editors: Pavlína Basařová and Vladimír Čablík

Received: 19 September 2021

Accepted: 25 October 2021

Published: 28 October 2021

Publisher's Note: MDPI stays neutral with regard to jurisdictional claims in published maps and institutional affiliations.

Copyright: () 2021 by the authors. Licensee MDPI, Basel, Switzerland. This article is an open access article distributed under the terms and conditions of the Creative Commons Attribution (CC BY) license (https:// creativecommons.org/licenses/by/ $4.0 /)$.

\begin{abstract}
As a common depressant, acidified water glass (AWG) has strong inhibitory effects on fluorite and calcite. The inhibited fluorite is difficult to be recovered, thus resulting in the waste of resources and low flotation efficiency. In this study, the interaction of fluoride ions with fluorite and calcite surfaces was investigated, and its effects of AWG adsorption on mineral surfaces were evaluated. Micro-flotation experiments indicated that the flotation recovery of fluorite is $88.72 \%$ after fluoride ion treatment, that is, approximately fourfold with respect to that without fluoride ion modification. The results of solution chemical calculations showed that $\mathrm{SiO}(\mathrm{OH})_{3}{ }^{-}$is the main component to inhibit fluorite, and $\mathrm{Si}(\mathrm{OH})_{4}$ is the main component to inhibit calcite in AWG solution. XPS and ICP-MS results showed that fluoride ions can improve the floatability of fluorite by converting $\mathrm{CaSiO}_{3}$ on the surface of fluorite into $\mathrm{CaF}_{2}$, but the conversion ability of $\mathrm{Si}(\mathrm{OH})_{4}$ on the surface of calcite is weak, which increases the difference in floatability between fluorite and calcite. The above results were further verified by the analysis of flotation foam image and contact angle measurement. After fluorine ion treatment, the contact angle of fluorite increased, and it was more easily adsorbed on the foam. Therefore, the interaction of the fluoride ion with the fluorite surfaces eliminated the adsorption of AWG on fluorite, thereby resulting in the enhanced hydrophobicity of fluorite. Different from the traditional metal ions modification, the idea of anion modification in this paper is expected to be further studied.
\end{abstract}

Keywords: fluorite; calcite; fluoride ion; surface modification; flotation

\section{Introduction}

Fluorite $\left(\mathrm{CaF}_{2}\right)$ contains $48.67 \%$ fluorine by weight and is the main mineral source of fluorine-based chemicals and materials [1,2]. Fluorite is a nonrenewable strategic nonmetallic mineral resource that is widely used in new energy, new materials, optoelectronics, metallurgy, and other fields [3-6]. High-grade fluorite has high industrial and economic value. Flotation is considered to be a common process for separating and purifying highgrade fluorite $\left(\mathrm{CaF}_{2} \geq 97 \%\right)$ from mixed minerals, and fatty acid collectors are common collectors for the flotation of calcium minerals [7-9].

Fluorite is often associated with calcite $\left(\mathrm{CaCO}_{3}\right)$. Because calcite has active Ca sites similar to fluorite, the ability of fatty acid collectors to collect fluorite and calcite is similar. Therefore, it is difficult to separate fluorite and calcite effectively with collectors alone, and depressants are usually required [10-12]. Water glass $\left(\mathrm{Na}_{2} \mathrm{O} \cdot \mathrm{rSiO}_{2}, \mathrm{r}\right.$ stands for the "modulus" or ratio of sodium silicate) is a common depressant of calcite and silicate minerals. It is a series of chemicals composed of sodium oxide and silica in different proportions [13]. Water glass reduces the mineral floatability by physical or chemical adsorption on the mineral surface. In industrial production, the amount of water glass 
used is very high, which will strongly inhibit fluorite and gangue minerals, making the flotation of fluorite difficult [14].

To avoid this situation, water glass can be modified to improve its selectivity. The results show that acidified sodium silicate has better selectivity for calcite and silicate minerals and is conducive to reducing the dosage of reagent and accelerating the settling of tailings [15-17]. However, when the gangue mineral content in fluorite is high, this selectivity will be weakened [18-20]. Therefore, other auxiliary reagents need to be introduced to improve the selectivity of acidified sodium silicate further.

In previous studies, researchers usually used metal ions as auxiliary reagents to improve the selectivity of flotation reagents. Metal ions can improve flotation efficiency by direct interaction with reagents or surface modification of target minerals [21]. Cao used $\mathrm{Ca}^{2+}$ and water glass to inhibit bastnaesite, which enhanced the inhibitory effect of water glass on bastnaesite [22]; Sun used $\mathrm{Pb}$-water glass to separate fluorite and calcite. $\mathrm{Pb}^{2+}$ enhanced the selectivity of water glass and effectively achieved the separation of fluorite and calcite [23]; Dong used $\mathrm{Fe}^{3+}$ and citric acid to separate calcite and scheelite. $\mathrm{Fe}^{3+}$ enhanced the selectivity of citric acid for calcite and achieved high-efficiency flotation separation of scheelite and calcite [24]. In the flotation industry, substantial research progress has been made on the role of metal ions. Some metal ions (copper and lead ions) have been applied to industrial production as activators for the flotation of sulfide and oxidized ore [25-27].

Although the advantages of metal-ion modifying agents have been confirmed many times, research on the effect of anions on flotation depressants has rarely been reported. In the separation process of fluorite and calcite, fluorine ion is used as the original ion in the solution, which reduces the influence of external ions on flotation. This work studied the effect of $\mathrm{F}^{-}$on the inhibition of acidified water glass (AWG), which will provide a new method and theoretical basis for the elimination of the unwanted depression effect of AWG on fluorite.

\section{Materials and Methods}

\subsection{Materials and Reagents}

The fluorite and calcite samples used in this study are from mines in Yunnan, China. The initial ore sample was crushed into $2 \mathrm{~mm}$ particles, and the impurities were removed manually under a microscope. The X-ray diffraction patterns of the pure samples are shown in Figure 1. The analysis shows that these samples have high purity and can be regarded

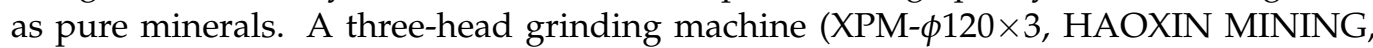
Ganzhou, China) was used for grinding. The milled products were screened, and the samples in the size range $38-74 \mu \mathrm{m}$ were sealed and stored for micro-flotation experiments and subsequent analysis.
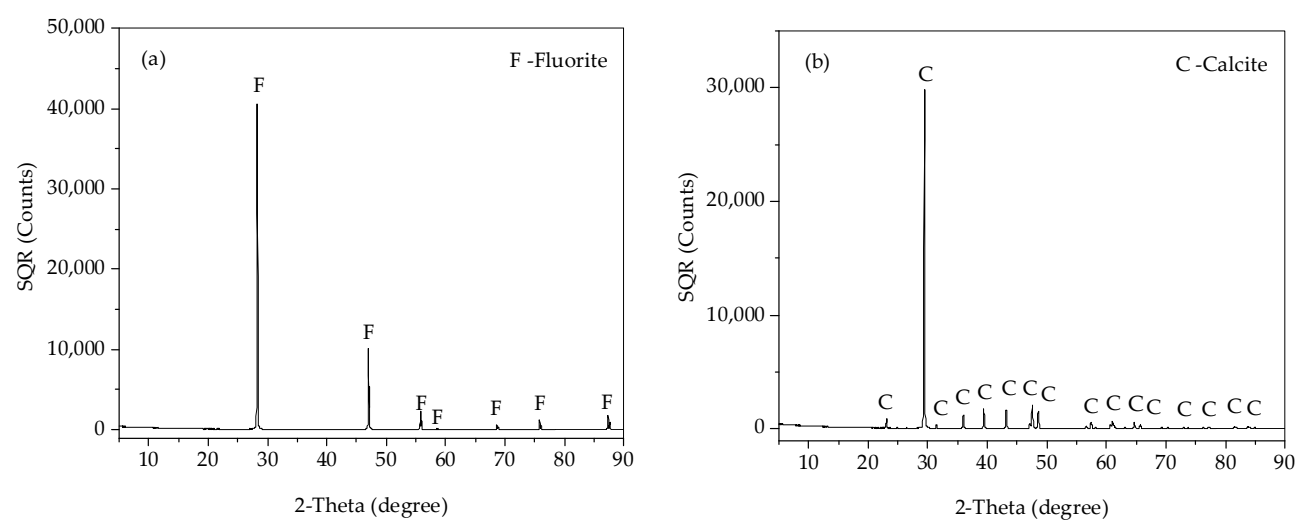

Figure 1. X-ray diffraction patterns of (a) pure fluorite and (b) pure calcite samples.

All reagents used in this study were analytical grade, and deionized water was used throughout the experiment. Sulfuric acid $(0.1 \mathrm{~mol} / \mathrm{L})$ and sodium hydroxide $(0.1 \mathrm{~mol} / \mathrm{L})$ 
were used to adjust the $\mathrm{pH}$ of the solution. Sulfuric acid and sodium hydroxide were obtained from Sinopharm Chemical Reagent $\mathrm{Co}$., Ltd. Sodium oleate $\left(\mathrm{NaOL}, \mathrm{C}_{18} \mathrm{H}_{33} \mathrm{NaO}_{2}\right.$ ) and sodium fluoride $(\mathrm{NaF})$, used as collectors and auxiliary reagents, respectively, were purchased from Tianjin Kemi Chemical Reagent Development Center, China. The water glass solution $\left(\mathrm{Na}_{2} \mathrm{SiO}_{3} \cdot 9 \mathrm{H}_{2} \mathrm{O}\right)$ was stirred with a constant temperature magnetic stirrer, and the water glass solution was titrated with sulfuric acid until the $\mathrm{pH}$ of the solution was 8.2 to prepare the AWG used in the research.

\subsection{Micro-Flotation Experiments}

The micro-flotation experiments of single mineral and artificial mixed ore were carried out using an RK/FGC5-35 (Wuhan New Materials Industry Park, Wuhan, China) flotation machine at room temperature. The stirring speed of the flotation machine was $1600 \mathrm{rpm}$, and the airflow rate was $0.04 \mathrm{~m}^{3} / \mathrm{h}$. Before each experiment, the experimental equipment was cleaned with an ultrasonic cleaning machine. The experimental operations were as follows: (1) $2 \mathrm{~g}$ single mineral sample or artificial mixed ore sample ( $1 \mathrm{~g}$ fluorite $+1 \mathrm{~g}$ calcite) and $60 \mathrm{~mL}$ deionized water were added to the flotation cell, and sodium hydroxide or sulfuric acid was used to adjust the pH of the pulp. (2) AWG was added and stirred for $3 \mathrm{~min}$. When necessary, $\mathrm{NaF}$ was added and stirred for $3 \mathrm{~min}$. (3) $\mathrm{NaOL}$ was added and stirred for $2 \mathrm{~min}$. After $3 \mathrm{~min}$ aeration, the concentrate was collected using a manual forth scraper. (4) The concentrate and tailings were filtered, dried, and weighed. The flotation recovery was calculated according to the formulas:

$$
\begin{gathered}
\varepsilon=\frac{m_{1}}{m_{1}+m_{2}} \times 100 \%, \\
\varepsilon=\frac{m_{1} \times \beta}{\left(m_{1}+m_{2}\right) \times \alpha} \times 100 \% .
\end{gathered}
$$

Formula (1) is used to calculate the flotation recovery of a single mineral, where $m_{1}$ and $m_{2}$ are the mass of concentrate and tailings, respectively. Formula (2) is used to calculate the flotation recovery of artificial mixed ore, and $\alpha$ and $\beta$ represent the grades of fluorite raw ore and concentrate, respectively. Each experiment was conducted three times, and the results were averaged.

The optimum solution $\mathrm{pH}$ and reagent concentration obtained from the micro-flotation experiments was used for subsequent tests to prepare samples for analysis.

\subsection{Solution Chemistry}

To study the adsorption mechanism of water glass on fluorite and calcite, the proportions of different components and contents in water glass solutions with different values of $\mathrm{pH}$ at $25^{\circ} \mathrm{C}$ were calculated using Visual MINTEQ (Version 3.1). Then, the conditional solubility products of $\mathrm{CaF}_{2}, \mathrm{CaCO}_{3}$, and $\mathrm{CaSiO}_{3}$ at different $\mathrm{pH}$ values were calculated using the conditional solubility product theory to analyze the species' transformation on the surface of fluorite and calcite.

\subsection{X-ray Photoelectron Spectroscopy Analysis}

X-ray photoelectron spectroscopy (XPS) test samples were prepared using a constant temperature magnetic stirrer. The fluorite $(2 \mathrm{~g})$ or calcite sample was mixed with $60 \mathrm{~mL}$ of deionized water, the $\mathrm{pH}$ of the solution was adjusted, and AWG or AWG $+\mathrm{NaF}$ were added as necessary. After stirring for $10 \mathrm{~min}$, the treated pulp was filtered with qualitative filter paper, and the filtered sample transferred to the vacuum furnace. After drying, fluorite and calcite samples without reagent, treated with AWG and AWG $+\mathrm{NaF}$, were analyzed using XPS. XPS data were obtained using a scanning XPS microprobe system (PHI 5000 Versa probe II, ULVAC-PHI, Kanagawa, Japan) with a monochromatic Al K $\alpha$ X-ray source. The pressure in the analyzer chamber was $10^{-7} \mathrm{~Pa}$. All binding energies of the measured spectra were calibrated using the $\mathrm{C} 1 \mathrm{~s}$ line at $284.8 \mathrm{eV}$. MultiPak 9.3 was used to fit the peaks to XPS data to determine the type and relative content of elements. 


\subsection{ICP-MS Tests}

The preparation process of test samples was as follows. Fluorite $(2 \mathrm{~g})$ or calcite was mixed with $60 \mathrm{~mL}$ deionized water in a beaker placed in a constant temperature magnetic stirrer at $25^{\circ} \mathrm{C}$, the $\mathrm{pH}$ of the solution was adjusted to 9 , and AWG was added to maintain its concentration in the solution at $30 \mathrm{mg} / \mathrm{L}$, stirred for $3 \mathrm{~min}$, and then $\mathrm{NaF}$ added in sequence according to the set concentration gradient. After stirring for $3 \mathrm{~min}$, the pulp was filtered and the filtrate stored. The Si concentration in each filtrate was measured using ICP-MS (7700× , Agilent, Santa Clara, CA, USA).

\subsection{Flotation Froth Imaging}

The flotation froth imaging is acquired with a SD-U500 industrial camera device. Fluorite $(2 \mathrm{~g})$ or calcite was added to $60 \mathrm{~mL}$ deionized water in a transparent foaming device, the pulp pH was adjusted to 9, and AWG and AWG + NaF were added as necessary, stirred for $3 \mathrm{~min}$, and then aerated. When the number of bubbles was large and evenly distributed, the surface bubble image was captured using a CCD high-speed industrial camera; then, the data were transmitted to the computer through the network, and the image was processed using ImageView (Version 9.0).

\subsection{Contact Angle Measurements}

Contact angle measurements were performed with a JY-82A (Chengde Dingsheng Advertising Co., Ltd., Chengde, China) video-based contact angle measuring device. Mineral crystals were ground with a diamond disk and then polished with $0.05 \mu \mathrm{m}$ alumina powder solutions on a polishing cloth. The preparation process of samples was the same as that of flotation tests, except $\mathrm{NaOL}$ was not added. First, the required medicament was added to the solution containing mineral crystal and stirred for 15 minutes; then, the solution $\mathrm{pH}=9$ was adjusted,, the mineral wafers were removed and dried naturally, and the contact angle with JY-82A was measured.

\section{Results and Discussions}

\subsection{Micro-Flotation Experiments}

Figure 2 shows the effect of pulp pH and dosage of AWG on the recovery of fluorite and calcite with NaOL as a collector and AWG as a depressant. Previous studies have shown that the optimal separation $\mathrm{pH}$ of calcite and fluorite appears in the weak alkaline environment close to 9 , which is due to the problems of increased mineral solubility, poor reagent selectivity, and difficult adjustment in the acidic and weak alkaline environment. In this study, the $\mathrm{pH}$ range is $7-11$, including the optimal $\mathrm{pH}$ for the separation of fluorite and calcite $[15,23,28]$ Figure $2 \mathrm{a}$ shows that, in the $\mathrm{pH}$ range of $7-11$, the flotation recovery of fluorite increases first and then decreases with the increase of solution $\mathrm{pH}$, and the flotation recovery of calcite decreases first and then increases with the increase of solution $\mathrm{pH}$. For $\mathrm{pH}>9$, the recovery of fluorite was greater than that of calcite. For $\mathrm{pH}=9$, the flotation recovery of the two minerals was similar, and the flotation recovery of calcite was the lowest. For $\mathrm{pH}<9$, the flotation recovery of fluorite was lower than that of calcite. Figure $2 \mathrm{~b}$ shows that, when $\mathrm{pH}=9$, the flotation recovery of fluorite and calcite decreases with the increase of AWG dosage, and the flotation recovery of fluorite is always lower than that of calcite. When the dosage of AWG reached $30 \mathrm{mg} / \mathrm{L}$, the recovery of calcite is significantly reduced to $22.11 \%$, and the recovery of fluorite remained unchanged, which is most conducive to the separation of the two. These results show that the pulp pH has a great influence on the inhibition of AWG. When AWG is used as a depressant alone, fluorite and calcite will be strongly inhibited. The difference between their floatability is small, so it is difficult to separate fluorite from calcite. 

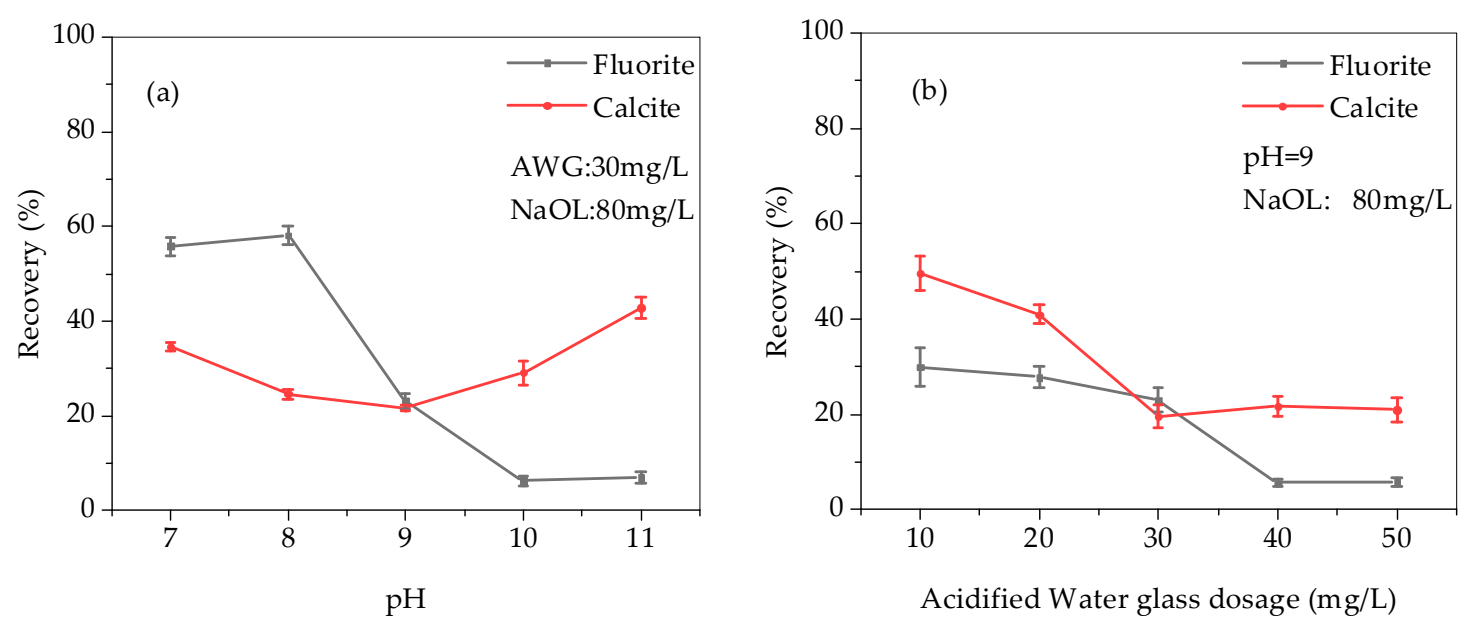

Figure 2. Effect of (a) $\mathrm{pH}$ value and (b) dosage of acidified water glass on the recovery of fluorite and calcite.

Figure 3 shows the effects of $\mathrm{NaF}$ dosage and pulp $\mathrm{pH}$ on the flotation recovery of fluorite and calcite with $\mathrm{NaOL}$ as collector and AWG as a depressant. The results show that, with the increase in the amount of sodium fluoride, the flotation recovery of the two minerals gradually increases, and the flotation recovery of fluorite increases greatly. When the recovery of fluorite reached $88.72 \%$, it was much higher than that of calcite at $34.85 \%$. The difference between the flotation recovery of fluorite and calcite is the largest under neutral or weakly alkaline conditions, which is most conducive to the separation of fluorite and calcite.
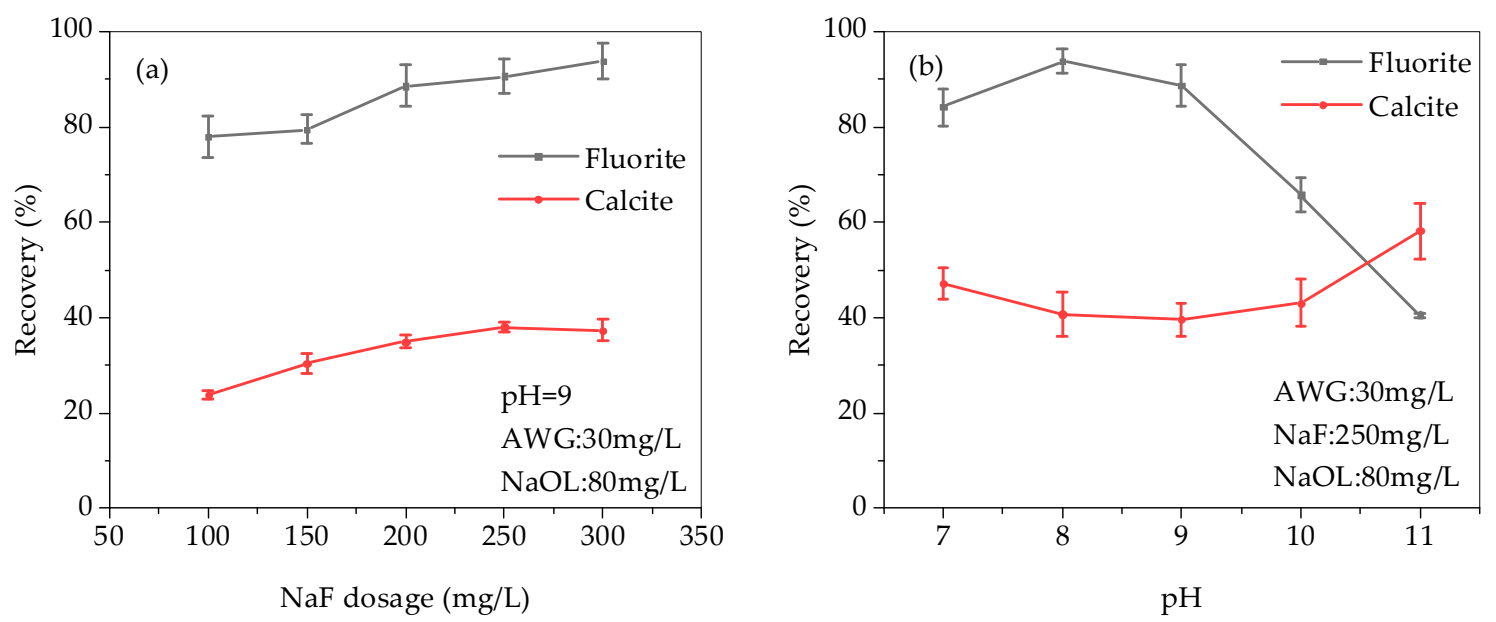

Figure 3. Effect of (a) dosage of $\mathrm{NaF}$ and (b) $\mathrm{pH}$ value on the recovery of fluorite and calcite.

To verify the effect of the fluoride ion on the flotation separation of fluorite and calcite with AWG as a depressant, the flotation tests of inhibiting calcite and collecting fluorite were designed for the artificial mixed ore. The experimental conditions were as follows: $\mathrm{pH}=9$, AWG $(30 \mathrm{mg} / \mathrm{L})$ as depressant, $\mathrm{NaOL}(250 \mathrm{mg} / \mathrm{L})$ as collector, and $\mathrm{NaF}(80 \mathrm{mg} / \mathrm{L})$ as auxiliary reagent. The mixture was passed through a roughing stage to obtain fluorite concentrate. The experimental results are shown in Tables 1 and 2. After adding $\mathrm{NaF}$, the grade of fluorite in the concentrate increased from $35.26 \%$ to $61.08 \%$, and the grade of calcite decreased from $64.74 \%$ to $38.92 \%$, indicating that the addition of a fluoride ion can significantly improve the flotation separation effect of fluorite and calcite. 
Table 1. Microflotation results for artificial mixed ore before NaF pretreatment.

\begin{tabular}{ccccccc}
\hline Products & Yield (\%) & Fluorite Grade (\%) & Fluorite Recovery (\%) & Calcite Grade (\%) & Calcite Recovery (\%) \\
\hline Concentrate & 16.45 & 35.26 & 11.60 & 64.74 & 21.30 \\
\hline Tailings & 83.55 & 52.90 & 88.40 & 47.10 & 78.70 \\
\hline Feed & 100 & 50 & 100 & 50 & 100 \\
\hline
\end{tabular}

Table 2. Microflotation results for artificial mixed ore after NaF pretreatment.

\begin{tabular}{ccccccc}
\hline Products & Yield (\%) & Fluorite Grade (\%) & Fluorite Recovery (\%) & Calcite Grade (\%) & Calcite Recovery (\%) \\
\hline Concentrate & 46.46 & 61.08 & 56.76 & 38.92 & 36.16 \\
\hline Tailings & 53.54 & 40.38 & 43.24 & 59.62 & 63.84 \\
\hline Feed & 100 & 50 & 100 & 50 & 100 \\
\hline
\end{tabular}

\subsection{Solution Chemistry}

The Visual MINTEQ model is widely used to calculate the morphology, solubility equilibria, and adsorption of ions in solution [29-32]. It can reflect the ion concentration and potential products in flotation pulp. The effect of $\mathrm{pH}$ on the composition and content of the water glass solution system is shown in Figure 4.

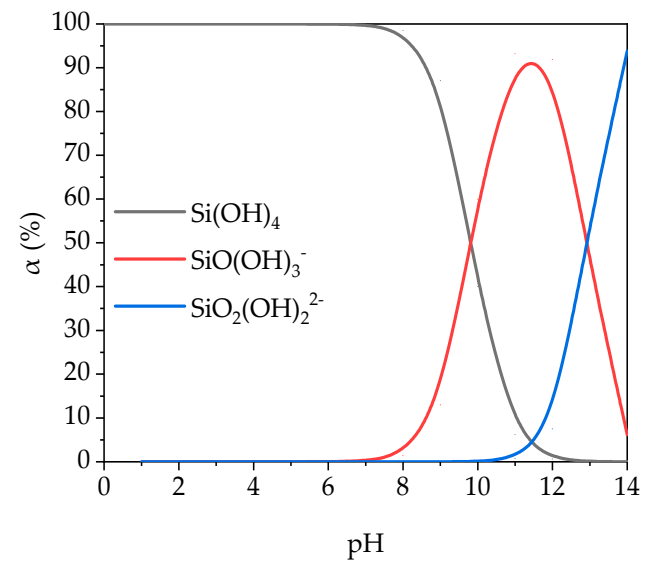

Figure 4. Effect of $\mathrm{pH}$ on the speciation and content of $\mathrm{Si}$ in a water glass solution.

According to Figure 4, it is inferred that the main reactions in the water glass solution system are as follows:

$$
\begin{gathered}
\mathrm{SiO}_{2(\mathrm{~s})}+2 \mathrm{H}_{2} \mathrm{O} \rightleftharpoons \mathrm{Si}(\mathrm{OH})_{4(\mathrm{aq})} \\
\mathrm{SiO}_{2}(\mathrm{OH})_{2}^{2-}+\mathrm{H}^{+} \rightleftharpoons \mathrm{SiO}(\mathrm{OH})_{3}^{-} \\
\mathrm{SiO}(\mathrm{OH})_{3}^{-}+\mathrm{H}^{+} \rightleftharpoons \mathrm{Si}(\mathrm{OH})_{4}
\end{gathered}
$$

Figure 4 shows that in the water glass solution, the dissociated $\mathrm{SiO}_{2}$ exists in the form of $\mathrm{Si}(\mathrm{OH})_{4}, \mathrm{SiO}(\mathrm{OH})_{3}{ }^{-}$, and $\mathrm{SiO}_{2}(\mathrm{OH})_{2}{ }^{2-}$. A large number of studies showed that $\mathrm{SiO}(\mathrm{OH})_{3}{ }^{-}$and $\mathrm{Si}(\mathrm{OH})_{4}$ are the main components of water glass to inhibit calcite and fluorite [13,33]. Comparing Figure $2 \mathrm{a}$, when $\mathrm{pH}<9.4, \mathrm{Si}(\mathrm{OH})_{4}$ is the dominant component, and the recovery rate of fluorite is higher than that of calcite. When $9.4 \leq \mathrm{pH} \leq 12.6$, $\mathrm{SiO}(\mathrm{OH})_{3}{ }^{-}$is the dominant component, and the recovery of calcite is higher than that of fluorite. The results show that $\mathrm{Si}(\mathrm{OH})_{4}$ is the main component to inhibit calcite, while $\mathrm{SiO}(\mathrm{OH})_{3}{ }^{-}$is the main component to inhibit fluorite. In $\mathrm{AWG}$, the $\mathrm{H}^{+}$from acid will combine with $\mathrm{SiO}_{2}(\mathrm{OH})_{2}{ }^{2-}$ and $\mathrm{SiO}(\mathrm{OH})_{3}{ }^{-}$ions in water glass solution, promoting the forward progress of reactions (4) and (5), generating more $\mathrm{Si}(\mathrm{OH})_{4}$, and enhancing the inhibitory effect of sodium silicate on calcite. 
Solution chemical calculations are widely used to study dissolution/precipitation characteristics and surface species transformation [34,35]. $K_{\mathrm{sp}}$ is called the solubility product of minerals, which depends on ionic strength and temperature. During the dissolution of $\mathrm{CaF}_{2}, \mathrm{CaCO}_{3}$, and $\mathrm{CaSiO}_{3}$, with the hydrolysis of $\mathrm{Ca}^{2+}$ and the proton addition reaction of $\mathrm{F}^{-}, \mathrm{CO}_{3}{ }^{2-}$, and $\mathrm{SiO}_{3}{ }^{2-}$, the solubility of minerals will be affected accordingly. The conditional solubility product $\mathrm{K}_{\mathrm{sp}}^{\prime}$ of $\mathrm{CaF}_{2}, \mathrm{CaCO}_{3}$, and $\mathrm{CaSiO}_{3}$ is calculated using the equilibrium formula and thermodynamic data in Table $3[34,36,37]$.

Table 3. Pertinent reactions and thermodynamic data for calculating the conditional solubility products of $\mathrm{CaF}_{2}, \mathrm{CaCO}_{3}$, and $\mathrm{CaSiO}_{3}$.

\begin{tabular}{|c|c|c|}
\hline Species & \multicolumn{2}{|c|}{ Pertinent Reactions and Constants } \\
\hline $\mathrm{Ca}^{2+}$ & $\begin{array}{c}\mathrm{Ca}^{2+}+\mathrm{OH}^{-} \rightleftharpoons \mathrm{Ca}(\mathrm{OH})^{+} \\
\mathrm{Ca}^{2+}+2 \mathrm{OH}^{-} \rightleftharpoons \mathrm{Ca}(\mathrm{OH})_{2(\mathrm{aq})} \\
\alpha_{\mathrm{Ca}}=1+K_{1}\left[\mathrm{OH}^{-}\right]+K_{2}\left[\mathrm{OH}^{-}\right]^{2}\end{array}$ & $\begin{array}{l}K_{1}=10^{1.4} \\
K_{2}=10^{2.77}\end{array}$ \\
\hline $\mathrm{CaF}_{2}$ & $\begin{array}{c}\mathrm{Ca}^{2+}+\mathrm{F}^{-} \rightleftharpoons \mathrm{CaF}_{2(\mathrm{~s})} \\
\mathrm{F}^{-}+\mathrm{H}^{+} \rightleftharpoons \mathrm{HF} \\
\alpha_{F}=1+K^{H}\left[H^{+}\right] \\
K_{s p C a-F}^{\prime}=K_{s p} \alpha_{C a} \alpha_{F}\end{array}$ & $\begin{array}{c}K_{s p C a-F}=10^{-10.41} \\
K^{H}=10^{3.4}\end{array}$ \\
\hline $\mathrm{CaCO}_{3}$ & $\begin{array}{c}\mathrm{Ca}^{2+}+\mathrm{CO}_{3}^{2-} \rightleftharpoons \mathrm{CaCO}_{3(\mathrm{~s})} \\
\mathrm{H}^{+}+\mathrm{CO}_{3}^{2-} \rightleftharpoons \mathrm{HCO}_{3}^{-} \\
\mathrm{H}^{+}+\mathrm{HCO}_{3}^{-} \rightleftharpoons \mathrm{H}_{2} \mathrm{CO}_{3} \\
\alpha_{C}=1+K_{1}^{H}\left[H^{+}\right]+K_{1}^{H} K_{2}^{H}\left[H^{+}\right]^{2} \\
K_{s p C a-C}^{\prime}=K_{s p} \alpha_{C a} \alpha_{c}\end{array}$ & $\begin{array}{c}K_{s p C a-C}=10^{-8.35} \\
K_{1}^{H}=10^{10.33} \\
K_{2}^{H}=10^{6.35}\end{array}$ \\
\hline $\mathrm{CaSiO}_{3}$ & $\begin{array}{c}\mathrm{Ca}^{2+}+\mathrm{SiO}_{3}^{2-} \rightleftharpoons \mathrm{CaSiO}_{3(\mathrm{~s})} \\
\mathrm{H}^{+}+\mathrm{SiO}_{3}^{2-} \rightleftharpoons \mathrm{HSiO}_{3}^{-} \\
\mathrm{H}^{+}+\mathrm{HSiO}_{3}^{-} \rightleftharpoons \mathrm{H}_{2} \mathrm{SiO}_{3} \\
\alpha_{S i}=1+K_{1}^{H}\left[H^{+}\right]+K_{1}^{H} K_{2}^{H}\left[H^{+}\right]^{2} \\
K_{s p C a-S i}^{\prime}=K_{s p} \alpha_{C a} \alpha_{S i}\end{array}$ & $\begin{array}{c}K_{s p C a-S i}=10^{-11.08} \\
K_{1}^{H}=10^{12.56} \\
K_{2}^{H}=10^{9.43}\end{array}$ \\
\hline
\end{tabular}

Figure 5 shows the $\mathrm{pH}-\log K_{\text {sp }}^{\prime}$ relationships for the three minerals. The smaller the value of $\log K^{\prime}$ sp, the more difficult it is to dissolve the precipitate. Figure 5 shows that when $6<\mathrm{pH}<9$, the order of conditional solubility products is $\mathrm{CaF}_{2}<\mathrm{CaCO}_{3}<\mathrm{CaSiO}_{3}$. When $9<\mathrm{pH}<12$, the order of conditional solubility products is $\mathrm{CaF}_{2}<\mathrm{CaSiO}_{3}<\mathrm{CaCO}_{3}$. When the pulp $\mathrm{pH}$ is in the range of $6-12$, the conditional solubility product of $\mathrm{CaF}_{2}$ is smaller than that of $\mathrm{CaCO}_{3}$ and $\mathrm{CaSiO}_{3}$, and $\mathrm{CaF}_{2}$ is easier to form than $\mathrm{CaCO}_{3}$ and $\mathrm{CaSiO}_{3}$. Therefore, adding $\mathrm{F}^{-}$to the pulp will preferentially generate $\mathrm{CaF}_{2}$ precipitate and transform the original $\mathrm{CaCO}_{3}$ and $\mathrm{CaSiO}_{3}$ precipitates. This indicates that fluoride ions may restore the floatability of fluorite by converting $\mathrm{CaSiO}_{3}$ on the surface of fluorite into $\mathrm{CaF}_{2}$, but the selectivity of fluoride ions is not clear and needs to be further studied.

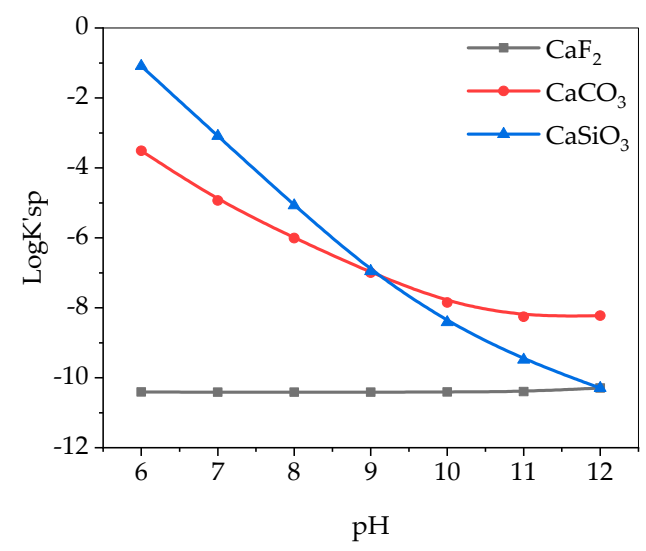

Figure 5. Effect of $\mathrm{pH}$ on the conditional solubility products of $\mathrm{CaF}_{2}, \mathrm{CaCO}_{3}$, and $\mathrm{CaSiO}_{3}$. 


\subsection{XPS Analysis}

The relative contents of the main elements on the surface of fluorite and calcite treated with AWG or AWG $+\mathrm{NaF}$ were analyzed using XPS. The results are shown in Tables 4 and 5. After $\mathrm{F}^{-}$treatment, the F1s content on the surface of fluorite and calcite increased by $1.42 \%$ and $0.99 \%$, respectively, and the Si2p content decreased by $0.83 \%$ and $1.17 \%$, respectively. This shows that fluoride ions are adsorbed on the surfaces of fluorite and calcite, and desorption of silicon-containing substances happens on the surfaces of fluorite and calcite.

Table 4. Relative content of surface elements of fluorite treated with different reagents.

\begin{tabular}{lcccc}
\hline & & \multicolumn{2}{c}{ Conditions } & Shift \\
& Elements & AWG & AWG + NaF & \\
\hline Concentration (\%) & Ca2p & 23.42 & 21.15 & -2.27 \\
& F1s & 24.80 & 26.22 & +1.42 \\
& O1s & 18.83 & 20.09 & +1.26 \\
& C1s & 28.82 & 29.24 & +0.42 \\
& Si2p & 4.13 & 3.30 & -0.83 \\
\hline
\end{tabular}

Table 5. Relative content of surface elements of calcite treated with different reagents.

\begin{tabular}{lcccc}
\hline & & \multicolumn{2}{c}{ Conditions } & Shift \\
& Elements & AWG & AWG + NaF & \\
\hline Concentration (\%) & Ca2p & 13.48 & 14.96 & +1.48 \\
& F1s & 0 & 0.99 & +0.99 \\
& O1s & 45.51 & 45.82 & +0.31 \\
& C1s & 38.81 & 37.20 & -1.61 \\
& Si2p & 2.20 & 1.03 & -1.17 \\
\hline
\end{tabular}

To explore further the effect of fluoride ions on the adsorption of AWG on the surface of fluorite and calcite, the high-resolution XPS spectrum of the Si2p peak was analyzed, and the results are shown in Figure 6. The Si2p XPS spectra of the fluorite surface treated with AWG and AWG + NaF are shown in Figure 6a,b. The peaks at 101.87 and $102.60 \mathrm{eV}$ in Figure 6a may be attributed to $\mathrm{Na}_{2} \mathrm{SiO}_{3}$ and $\mathrm{CaSiO}_{3}$, respectively [38]. After $\mathrm{F}^{-}$treatment, it is observed in Figure $6 \mathrm{~b}$ that the peak area corresponding to $\mathrm{CaSiO}_{3}$ decreases from $62.02 \%$ to $34.31 \%$, indicating that part of $\mathrm{CaSiO}_{3}$ on the surface of fluorite is converted into $\mathrm{CaF}_{2}$ by fluoride ions, so the inhibition of fluorite is weakened.

The Si2p spectra of the calcite surface treated with AWG and AWG $+\mathrm{NaF}$ are shown in Figure $6 c$,d. The peaks at 101.64 and $102.41 \mathrm{eV}$ in Figure $6 \mathrm{c}$ can also be attributed to $\mathrm{Na}_{2} \mathrm{SiO}_{3}$ and $\mathrm{CaSiO}_{3}[39,40]$. It can be clearly observed that a peak different from fluorite appears at $103.21 \mathrm{eV}$ on the calcite surface, which can be attributed to the physical adsorption of $\mathrm{Si}(\mathrm{OH})_{4}$ on the calcite surface $[13,33,41]$. After $\mathrm{F}^{-}$treatment, it is observed in Figure $6 \mathrm{~d}$ that the peak area corresponding to $\mathrm{CaSiO}_{3}$ decreases from $47.65 \%$ to $43.18 \%$, and the peak area corresponding to $\mathrm{Si}(\mathrm{OH})_{4}$ decreases from $23.21 \%$ to $20.89 \%$, indicating that although $\mathrm{CaSiO}_{3}$ on the calcite surface will also be desorbed by fluoride ions, the desorption ability of fluoride ions to $\mathrm{Si}(\mathrm{OH})_{4}$ is very weak, and $\mathrm{Si}(\mathrm{OH})_{4}$ is the main component to inhibit the floatability of calcite. As a result, calcite is still strongly inhibited. This shows that, although $\mathrm{CaSiO}_{3}$ on the surface of calcite will also be converted by fluoride ions, the conversion ability of fluoride ions with $\mathrm{Si}(\mathrm{OH})_{4}$ is very weak, which is the mechanism of fluoride ions improving the flotation separation efficiency of fluorite and calcite. 


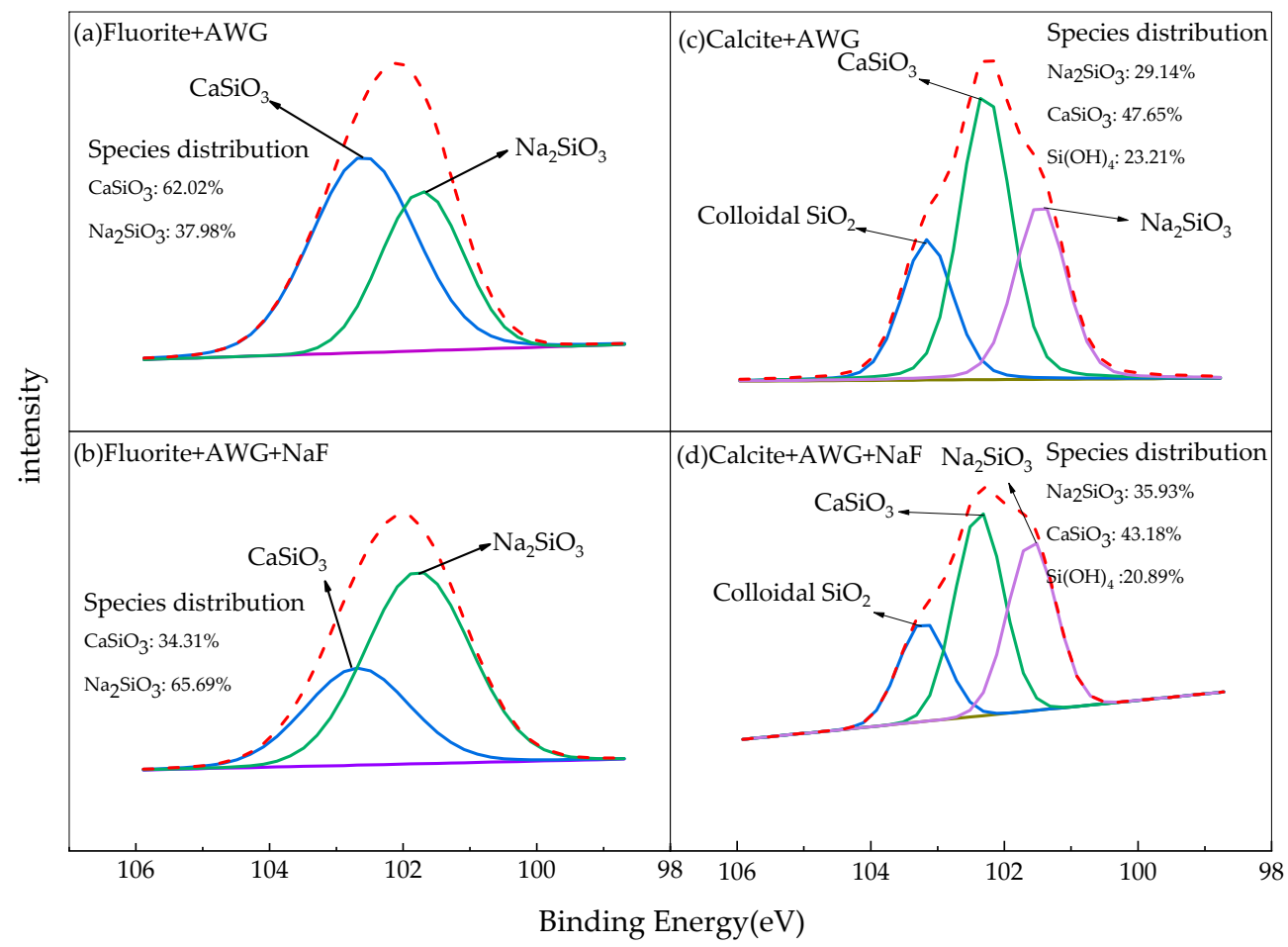

Figure 6. Si2p XPS spectra of (a) AWG-treated fluorite surface, (b) AWG + NaF-treated fluorite surface, (c) AWG-treated calcite surface, and (d) AWG + NaF-treated calcite surface.

\subsection{ICP-MS Tests}

Fluoride ions improve floatability by desorbing silicon adsorbed on the surface of fluorite and calcite. Under the condition of $30 \mathrm{mg} / \mathrm{L}$ AWG dosage, $\mathrm{NaF}$ of different concentrations was added and filtered after reaction, and the silicon concentration in each filtrate was measured using inductively coupled plasma-mass spectrometry (ICP-MS). The change of silicon concentration in the filtrate with the amount of $\mathrm{NaF}$ is shown in Figure 7. With the increase in the number of fluoride ions, the desorption of fluoride ions is enhanced, the silicon on the mineral surface is gradually reduced, and the silicon concentration in the filtrate is increased. Under different $\mathrm{NaF}$ dosages, the silicon concentration in fluorite filtrate is higher than that of calcite, which proves that the effect of $\mathrm{F}^{-}$on the fluorite surface is stronger than that of the calcite surface, which is consistent with the conclusions of the microflotation experiment and XPS analysis.

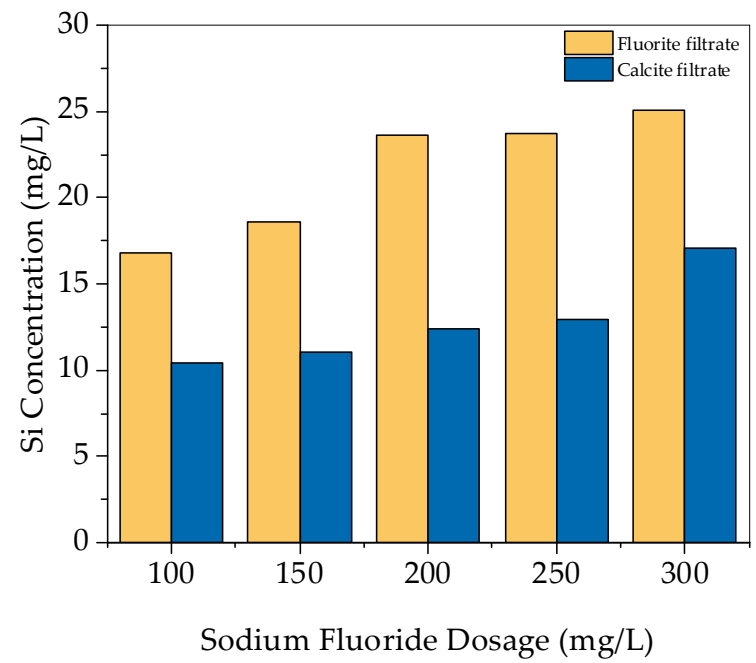

Figure 7. Effect of NaF dosage on silicon concentration in fluorite and calcite filtrate. 


\subsection{Image Analysis of Flotation Froth}

Flotation involves increasing the floatability difference between useful minerals and gangue minerals using additives so that hydrophobic minerals can be attached to flotation froth for separation purposes. Therefore, the flotation effect can be directly judged by observing the mineral attachment to the floating foam. Figure $8 \mathrm{a}, \mathrm{b}$ shows the fluorite flotation froth image processed with AWG or AWG $+\mathrm{NaF}$ and $80 \mathrm{mg} / \mathrm{L} \mathrm{NaOL}$. The floating foam in Figure 8a shows a large area of the transparent state, which means that fluorite is inhibited by AWG and cannot adsorb on the foam. After $\mathrm{F}^{-}$treatment, it was observed that the surface of the Figure $8 \mathrm{~b}$ foam was evenly covered by fluorite and showed good adsorption properties. Fluorite ore activated by fluoride ions shows strong adsorption capacity to foam, which greatly improves the floatability of fluorite, which is inhibited by AWG.
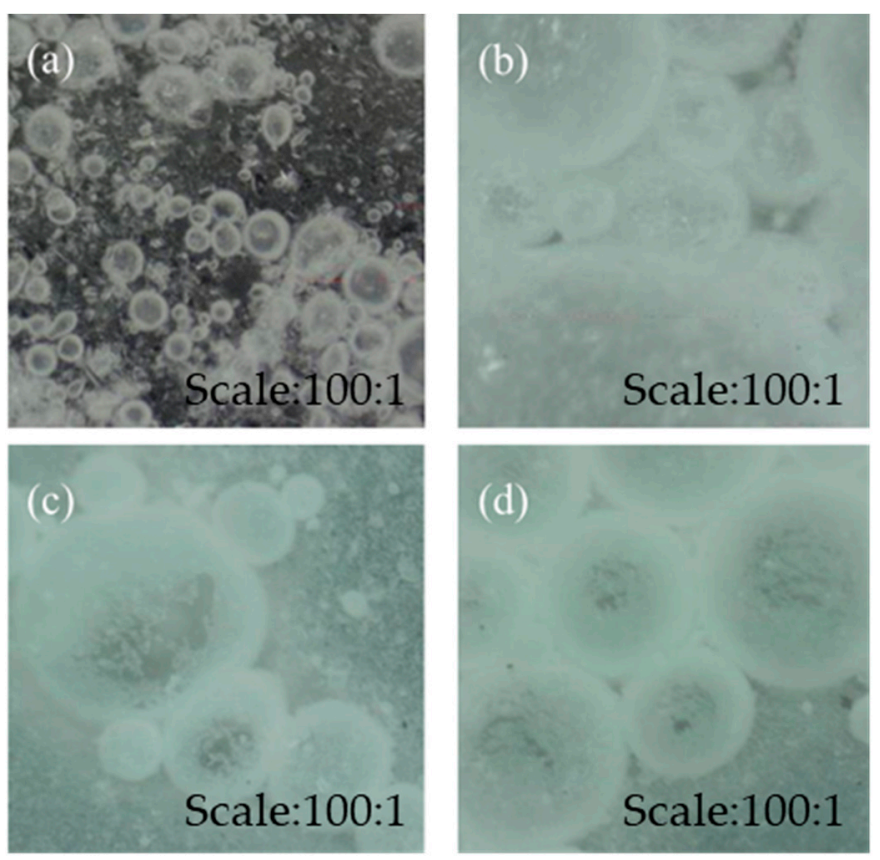

Figure 8. Foam image of (a) AWG-treated fluorite, (b) AWG + NaF-treated fluorite, (c) AWG-treated calcite, and (d) AWG + NaF-treated calcite.

Figure $8 \mathrm{c}, \mathrm{d}$ shows the image of calcite flotation froth treated with AWG or AWG + $\mathrm{NaF}$ and $80 \mathrm{mg} / \mathrm{L} \mathrm{NaOL}$. Comparing Figure $8 \mathrm{c}$ with Figure $8 \mathrm{~d}$, it is found that, before and after $\mathrm{NaF}$ addition, the center of the flotation cell shows a transparent part, and the area changes little. This indicates that the inhibition effect of AWG on calcite did not change with the addition of $\mathrm{NaF}$, and the calcite inhibited by the reaction could not be adsorbed onto the foam to be floated. It can be seen from the flotation froth image that the fluoride ion selectively improves the flotation effect of fluorite.

\subsection{Contact Angle Measurement Results}

The contact angle measurement results of fluorite and calcite under different conditions are shown in the Table 6 . The contact angle is directed related to the floatability of mineral, and a larger contact angle generally indicates a more hydrophobic mineral surface [42].

As shown in the Table 6, under the condition of $\mathrm{pH}=9$, the contact angle between the untreated fluorite sample and calcite sample is close, indicating that their floatability is similar in natural state. After AWG treatment, the contact angle of fluorite samples decreased by $20.46^{\circ}$, and that of calcite samples decreased by $18.67^{\circ}$, indicating that AWG had a strong inhibitory effect on calcite and fluorite. After AWG and NaF treatment, 
compared with AWG treatment alone, the contact angle of fluorite increased by $24.40^{\circ}$, and the floatability was greatly improved; The contact angle of calcite only increased by $0.76^{\circ}$, and the change of floatability was small. The change of contact angle between fluorite and calcite shows that the fluoride ion selectively improves the floatability of fluorite inhibited by AWG, which is consistent with the above experimental conclusions.

Table 6. Contact angle between fluorite surface and calcite surface treated with different reagents.

\begin{tabular}{cccccc}
\hline & \multicolumn{5}{c}{ Contact Angle (Degree) } \\
\hline Species & Untreated & AWG-Treated & Shift & AWG + NaF-Treated & Shift \\
\hline Fluorite & 77.20 & 56.74 & -20.46 & 81.14 & +24.40 \\
Calcite & 76.38 & 57.71 & -18.67 & 58.47 & +0.76 \\
\hline
\end{tabular}

\section{Conclusions}

The effects of the fluoride ion on AWG selectivity and flotation separation of fluorite and calcite were studied using micro-flotation, solution chemistry, XPS, ICP-MS, flotation froth images, and contact angle measurement. The results of micro-flotation experiments show that after adding the fluoride ion, the flotation recovery of fluorite is greater than that of calcite, and the grade of fluorite concentrate obtained by manually mixed ore flotation is also greatly improved. ICP-MS results show that the fluoride ion was adsorbed by replacing the silicon ion on the mineral surface, and the adsorption on the fluorite surface was stronger than that on the calcite surface. The results of solution chemistry calculations and XPS analysis showed that $\mathrm{SiO}(\mathrm{OH})_{3}{ }^{-}$is the main component to inhibit fluorite and $\mathrm{Si}(\mathrm{OH})_{4}$ is the main component to inhibit calcite in water glass solution. The adsorption products of sodium silicate on the fluorite surface are mainly $\mathrm{CaSiO}_{3}$ and $\mathrm{Na}_{2} \mathrm{SiO}_{3}$, and the adsorption products on the calcite surface are mainly $\mathrm{CaSiO}_{3}, \mathrm{Na}_{2} \mathrm{SiO}_{3}$, and $\mathrm{Si}(\mathrm{OH})_{4}$. The fluoride ion can convert $\mathrm{CaSiO}_{3}$ adsorbed on the surface of fluorite into $\mathrm{CaF}_{2}$, but the effect of $\mathrm{Si}(\mathrm{OH})_{4}$ adsorbed on the surface of calcite is not obvious, which makes the difference of floatability between fluorite and calcite larger. The results of the flotation froth image and contact angle measurement showed that the fluoride ion enhanced the hydrophobicity of fluorite by increasing the contact angle of fluorite, and treated fluorite was more easily adsorbed on the foam. Therefore, the interaction of the fluoride ion with fluorite and calcite surface affected the adsorption of AWG on mineral surface. Fluoride ion modification makes fluorite obtain better hydrophobicity, and fluorite can be recovered as much as possible. The study provides experimental reference and theoretical basis for anionic modification and activated fluorite flotation.

Author Contributions: D.L. and Y.M. conceived of and designed the experiments. D.W. and R.S. performed the experiments and analyzed the data. R.L. contributed materials. D.W. wrote the paper. S.W. modified the paper. All authors have read and agreed to the published version of the manuscript.

Funding: This research project was supported by the State Key Laboratory of Complex Nonferrous Metal Resources Clean Utilization, Kunming University of Science and Technology (Open Fund Project Number is CNMRCUKF1904), China Postdoctoral Science Foundation (Grant No. 2018M633637XB), and Chemistry of Key Construction Disciplines for Master Degree Program in Yunnan (Grant No. HXZ1601).

Acknowledgments: We are grateful to the Analysis and Testing Centre in Kunming University of Science and Technology for technical support. We thank Ian McNaught for editing the English text of a draft of this manuscript.

Conflicts of Interest: The authors declare no conflict of interest. 


\section{References}

1. Pelham, L.J. Sources and availability of raw materials for fluorine chemistry. J. Fluor. Chem. 1985, 30, 1-17. [CrossRef]

2. Akgün, A.; Teğin, İ.; Minerals, R.Z.; Characterization, M. Engineering, Enrichment of Molybdenum and Fluorite by Flotation of Fluorite Ore Containing Molybdenum. J. Miner. Mater. Charact. Eng. 2006, 5, 103.

3. Masoudi, S.M.; Ezzati, E.; Rashidnejad-Omran, N.; Moradzadeh, A.J.R.P. Geoeconomics of fluorspar as strategic and critical mineral in Iran. Resour. Policy 2017, 52, 100-106. [CrossRef]

4. Liu, L.X.; Wang, S.J.; Dong, Y.C.; Jia, X.H. Performance of Low Fluoride Dephosphorization Slag of Hot Metal. J. Iron Steel Res. Int. 2011, 18, 11-15. [CrossRef]

5. Engelhardt, J.B.; Dabringhaus, H.; Wandelt, K. Atomic force microscopy study of the $\mathrm{CaF}_{2}(111)$ surface: From cleavage via island to evaporation topographies. Surf. Sci. 2000, 448, 187-200. [CrossRef]

6. Free, M.L.; Miller, J.D.J.L. Kinetics of 18Carbon Carboxylate Adsorption at the Fluorite Surface. Langmuir 1997, 13, 4377-4382. [CrossRef]

7. Zheng, R.; Ren, Z.; Gao, H.; Chen, Z.; Qian, Y.; Li, Y.J. Effects of crystal chemistry on sodium oleate adsorption on fluorite surface investigated by molecular dynamics simulation. Miner. Eng. 2018, 124, 77-85. [CrossRef]

8. Jia, W.H.; Qin, W.Q.; Chen, C.; Zhu, H.L.; Jiao, F.J. Collecting performance of vegetable oils in scheelite flotation and differential analysis. J. Cent. South Univ. 2019, 26, 787-795. [CrossRef]

9. Liu, J.; Xie, R.; Zhu, Y.; Li, Y.; Liu, C.J. Flotation behavior and mechanism of styrene phosphonic acid as collector on the flotation separation of fluorite from calcite. J. Mol. Liq. 2021, 326, 115261. [CrossRef]

10. Hanna, H.S.; Somasundaran, P. Flotation of Salt-Type Minerals; Columbia University: New York, NY, USA, 1976.

11. Filippova, I.V.; Filippov, L.O.; Duverger, A.; Severov, V.V. Synergetic effect of a mixture of anionic and nonionic reagents: Ca mineral contrast separation by flotation at neutral $\mathrm{pH}$-ScienceDirect. Miner. Eng. 2014, 66-68, 135-144. [CrossRef]

12. Houot, R.J. Beneficiation of phosphatic ores through flotation: Review of industrial applications and potential developments. Int. J. Miner. Process. 1982, 9, 353-384. [CrossRef]

13. Marinakis, K.I.; Shergold, H.L. Influence of sodium silicate addition on the adsorption of oleic acid by fluorite, calcite and barite. Int. J. Miner. Process. 1985, 14, 177-193. [CrossRef]

14. Kupka, N.; Rudolph, M.J. Technology, Froth flotation of scheelite-A review. Int. J. Min. Sci. Technol. 2017, 28, 373-384. [CrossRef]

15. Zhou, Q.; Lu, S.J. Acidized sodium silicate-An effective modifier in fluorite flotation. Miner. Eng. 1992, 5, 435-444. [CrossRef]

16. Zhou, W.; Moreno, J.; Torres, R.; Valle, H.; Song, S.J. Flotation of fluorite from ores by using acidized water glass as depressant. Miner. Eng. 2013, 45, 142-145. [CrossRef]

17. Ding, K.; Laskowski, J.S. Application of a modified water glass in a cationic flotation of calcite and dolomite \%. J. Can. Metall. Q. 2006, 45, 199-206. [CrossRef]

18. Asadi, M.; Mohammadi, M.; Moosakazemi, F.; Esmaeili, M.J.; Zakeri, M.J. Development of an environmentally friendly flowsheet to produce acid grade fluorite concentrate. J. Clean. Prod. 2018, 186, 782-798. [CrossRef]

19. Gao, Z.; Wang, C.; Sun, W.; Gao, Y.; Kowalczuk, P.B. Froth flotation of fluorite: A review. Adv. Colloid Interface Sci. 2021, 290, 102382. [CrossRef] [PubMed]

20. Agar, G.E.J.U. Scheelite Flotation Process; Vale Canada Ltd.: Burlington, ON, Canada, 1984.

21. Zyga, B.; Zyja, B.; Wei, S.; Ysg, C.J. Typical roles of metal ions in mineral flotation: A review. Trans. Nonferrous Met. Soc. China 2021, 31, 2081-2101.

22. Zhao, C.; Zc, A.; Jw, A.; Yc, A.J. Synergistic depression mechanism of $\mathrm{Ca}^{2+}$ ions and sodium silicate on bastnaesite flotation. J. Rare Earths 2021, in press. [CrossRef]

23. Sun, R.; Liu, D.; Liu, Y.; Wang, D.; Wen, S. Pb-water glass as a depressant in the flotation separation of fluorite from calcite. Colloids Surf. A Physicochem. Eng. Asp. 2021, 629, 127447. [CrossRef]

24. Dong, L.; Wei, Q.; Qin, W.; Science, F.J. Effect of iron ions as assistant depressant of citric acid on the flotation separation of scheelite from calcite. Chem. Eng. Sci. 2021, 241, 116720. [CrossRef]

25. Feng, Q.; Zhao, W.; Wen, S.; Cao, Q.J.S.; Technology, P. Activation mechanism of lead ions in cassiterite flotation with salicylhydroxamic acid as collector. Sep. Purif. Technol. 2017, 178, 193-199. [CrossRef]

26. Wang, H.; Wen, S.; Han, G.; Feng, Q.J. Modification of malachite surfaces with lead ions and its contribution to the sulfidization flotation. Appl. Surf. Sci. 2021, 550 (Pt 2), 149350. [CrossRef]

27. Zhao, W.; Liu, D.; Feng, Q.J. Enhancement of salicylhydroxamic acid adsorption by Pb(II). Miner. Eng. 2020, $152,106373$. [CrossRef]

28. Jin, S.; Ou, L.; Ma, X.; Zhou, H.; Zhang, Z.J. Activation mechanisms of sodium silicate-inhibited fluorite in flotation under neutral and slightly alkaline conditions-ScienceDirect. Miner. Eng. 2020, 161, 106738. [CrossRef]

29. Qiang, L.; Li, Y.; Zhang, J.; Ying, C.; Ruan, X.; Liu, J.; Qian, G.J. Effective removal of zinc from aqueous solution by hydrocalumite. Chem. Eng. J. 2011, 175, 33-38.

30. Markovski, J.S.; Marković, D.; Đokić, V.; Mitrić, M.; Journal, A.M. Arsenate adsorption on waste eggshell modified by goethite, $\alpha-\mathrm{MnO}_{2}$ and goethite/ $\alpha-\mathrm{MnO}_{2}$. Chem. Eng. J. 2014, 237, 430-442. [CrossRef]

31. Wang, X.; Zhang, Y.; Liu, T.; Cai, Z.J.C.; Physicochemical, S.A.; Aspects, E. Influence of metal ions on muscovite and calcite flotation: With respect to the pre-treatment of vanadium bearing stone coal. Colloids Surf. A Physicochem. Eng. Asp. 2019, 564, 89-94. [CrossRef] 
32. Li, C.; Bai, S.; Ding, Z.; Yu, P.; Wen, S. Visual MINTEQ model, ToF-SIMS, and XPS study of smithsonite surface sulfidation behavior: Zinc sulfide precipitation adsorption. J. Taiwan Inst. Chem. Eng. 2019, 96, 53-62. [CrossRef]

33. Foucaud, Y.; Badawi, M.; Filippov, L.O.; Barres, O.; Filippova, I.V.; Lebègue, S. Synergistic adsorptions of Na2CO3 and Na2SiO3 on calcium minerals revealed by spectroscopic and ab initio molecular dynamics studies. Chem. Sci. 2019, 10, 9928-9940. [CrossRef]

34. $\mathrm{Hu}, \mathrm{Y}$;; Chi, R.; Xu, Z.J.I.; Research, E.C. Solution Chemistry Study of Salt-type Mineral Flotation Systems: Role of Inorganic Dispersants. Ind. Eng. Chem. Res. 2003, 42, 1641-1647.

35. Wang, D.J. Chapter 3 Mineral-solution equilibria. Dev. Miner. Process. 2006, 17, 45-72.

36. Martell, A.E.; Smith, R.M. Critical Stability Constants; Plenum Press: New York, NY, USA, 1975.

37. Amankonah, J.O.; Somasundaran, P.; Ananthapadmabhan, K.P.J.C. Surfaces, Effects of dissolved mineral species on the dissolution/ precipitation characteristics of calcite and apatite-ScienceDirect. Colloids Surf. 1985, 15, 295-307. [CrossRef]

38. Tian, J.; Xu, L.; Sun, W.; Zeng, X.; Fang, S.; Han, H.; Hong, K.; Hu, Y.J. Use of $\mathrm{Al}_{2}\left(\mathrm{SO}_{4}\right)_{3}$ and acidified water glass as mixture depressants in flotation separation of fluorite from calcite and celestite. Miner. Eng. 2019, 137, 160-170. [CrossRef]

39. Kaneko, Y.; Suginohara, Y.J. Observation of Si 2p Binding Energy by ESCA and Determination of $\mathrm{O}^{0}, \mathrm{O}^{-}$and $\mathrm{O}^{2-}$ Ions in Silicate. J. Jpn. Inst. Met. 1978, 42, 285-289. [CrossRef]

40. Wei, J.; Gao, Z.; Khoso, S.A.; Gao, J.; Wei, S.; Wei, P.; Hu, Y.J. Selective adsorption of benzhydroxamic acid on fluorite rendering selective separation of fluorite/calcite. Appl. Surf. Sci. 2018, 435, 752-758.

41. NIST XPS Database. Available online: https://srdata.nist.gov/xps/selEnergyType.aspx (accessed on 15 September 2012).

42. Chen, W.; Feng, Q.; Zhang, G.; Yang, Q.; Zhang, C.; Xu, F.J. The flotation separation of scheelite from calcite and fluorite using dextran sulfate sodium as depressant. Int. J. Miner. Process. 2017, 169, 53-59. [CrossRef] 